\title{
On the investigation of providing space truss roofs with ductility until failure under monotonically increasing vertical loads
}

\section{Uzay kafes çatı sistemlerinin artan düşey yükler altında sünekliğinin araştırılması}

\author{
Cüneyt VATANSEVER ${ }^{1}$ (iD), Haluk Emre ALÇIÇEK ${ }^{2}$ (D) \\ 1,2Department of Civil Engineering, Faculty of Civil Engineering, İstanbul Technical University, Istanbul, Turkey. \\ cuneyt.vatansever@itu.edu.tr, alcicek@itu.edu.tr
}

\begin{abstract}
The aim of this paper is to investigate the nonlinear behavior of space truss roofs subject to different load accumulation forms considering the effect of initial imperfection and slenderness ratio of the truss members. For this, a typical space truss roof using MERO-connection type with flat double-layer was selected as a sample. $3 D$ model of the roof was developed and analyzed by using OpenSEES. Nonlinear behavior of each typical bar of the space truss roof, which, was mainly composed of particular sub-elements such as a tubular element, bolts, sleeves and spheres was represented by a single truss bar. Axial load-displacement relationship of each single truss bar was obtained from nonlinear analysis performed under reversal cyclic loading. Besides, three different types of load distribution that simulates accumulation of rainwater or drifted snow were taken into account as an external load acting on upper layer of the roof system. Analyses results showed that load carrying capacity of the space truss roofs was susceptible to the form of accumulation and reduces abnormally when the accumulation, in particular, occurred locally. Furthermore, failure mode of the system designed with optimal solution was dominated by buckled truss bars and brittle failure occurred. Also initial imperfection had a negative effect on the members in compression.
\end{abstract}

Keywords: Space truss roof, MERO-connection, Initial imperfection, load accumulation.

\section{Introduction}

Space truss roofs are desirable as a load bearing systems under vertical loads because their self-weight may be considerably decreased and as a consequence many additional advantages such as sufficient stiffness in horizontal plane, ease of erection, lower cost, architectural flexibility, and versatility of form may be provided.

Even though space truss roofs have high degree of indeterminacy [1], they are very prone to accumulation of rainwater and drifted snow [2]. Further, total or partial collapses of these systems mostly occurs due to uneven distribution of these loads on the roofs rather than wind or earthquake loads. The implementation of parapets around a roof perimeter and clogging of the drainage system are the main reasons that cause the accumulation of rainwater and snow, respectively. To reveal the collapse behavior of space truss roofs due to ponding, substantial investigations were performed by Biegus and Rykaluk [3], Piroglu et al. [4], Piroglu and Ozakgul [5]. Inadequacy of standards and misestimating of

\begin{abstract}
Öz
Bu çalıșmada uzay kafes çatı sistemlerinin çeşitli yük birikme senaryoları altındaki doğrusal olmayan davranıșı, cubuk eleman başlangıç kusurları ve çubuk eleman narinlikleri de dikkate alınarak incelenmistir. MERO düğüm noktasına sahip iki adet örnek uzay kafes çatı sistemi OpenSEES yazılımı üç boyutlu olarak modellenerek analizler gerçekleștirilmiștir. Bulonlar, somunlar ve düğüm noktası kürelerinden olușan her bir çubuk elemanın davranıșı tekil çubuklar üzerinde tanımlanarak genel sisteme aktarılmıștır. Her bir çubuk elemanın eksenel yük-yerdeğistirme davranısları çevrimsel tekrarlı yükler altında analizler gerçekleştirilerek elde edilmiştir. Genel sistem analizleri çatının tamamında, yarısında ve dörtte birinde yağmur suyu veya kar yükü yığılmalarını yansıtacak șekilde belirlenen yükleme altında gerçekleștirilmiștir. Analizler sonucunda uzay kafes çatı sistemlerinin yük yığılmalarına karșı hassas oldukları ve lokal bölgelerde oluşan yük yığılmalarının sistemin tașıma kapasitesini düșürdüğü görülmüstür. Bunun yanında, en ekonomik kesitlerle boyutlandırılan sistemde göçme basınç çubuklarının burkulması ile gevrek bir sekilde meydana gelmistir. Ayrıca, çalıșma kapsamında başlangıç kusurlarının çubuk elemanların basınç kapasitelerini düşürdüğü görülmüștür.
\end{abstract}

Anahtar kelimeler: Uzay kafes çatı sistemleri MERO düğüm noktası Bașlangıç kusuru, Yük yığılması.

these loads are the most common factors that bring about exceeding design loads and in turn causing local or total collapse of roof structures.

Rosen and Schmit [6] investigated the effects of member imperfections and system imperfection on the behavior of structural system. El-Sheikh [7] presented a numerical study on triple-layer space trusses to determine the sensitivity of the space trusses to the length imperfections that were likely to be formed by too long and too short members, resulting in a lack of fit.

Besides manufacturing process causes initial imperfection defined as initial out-of-straightness of truss bars. Then, this increases the second order effects leading to reduction in compressive strength due to presence of bending [8]. Buckling behavior of steel members with regard to varying initial imperfections is investigated by Uriz, Filippou, and Mahin [9], Lee and Noh [10]. According to these researches, the critical buckling load of a brace decreases as long as the amount of

${ }^{*}$ Corresponding author/Yazışılan Yazar 
initial imperfection increases. However, post buckling behavior is not influenced much by initial imperfection.

This paper presents the nonlinear analyses results of the MERO system space roof trusses considering the various scenarios of rainwater or snow accumulation on the roof. Therefore, the vulnerability of the roof systems to these loading cases was investigated through nonlinear analyses using OpenSEES (Open System for Earthquake Engineering Simulation) [11] For this, several nonlinear pushover analyses in vertical direction were applied on the analytical models of the roofs to obtain the load-displacement characteristics of them depending on the accumulation form. In the analyses, three different accumulation forms; a quarter, a half and entire upper surface of the roof were taken into account, and two different quantities of initial imperfections for the truss members were also considered in the computer models. Hence, the effect of the initial geometric imperfection imposed on the truss bars and then the general behaviors of the systems were examined.

\section{Sample space roof truss systems}

In order to investigate the nonlinear behavior of space truss roofs, a typical space truss roof using MERO-connection type with flat double-layer was selected, and two geometrically identical computer models, which, denoted by Model A and Model B were considered. The truss roofs had span of $15 \mathrm{~m}$ on both $\mathrm{x}$ and $\mathrm{y}$ directions and a height of $1.5 \mathrm{~m}$ between upper and lower layer, were simply supported on four corner nodes at the level of lower layer. The square-on-square models were arranged with $5 \times 5$ square modules with the sizes of $3 \mathrm{~m} \times 3 \mathrm{~m}$. Plan and elevation view of the roof system are shown in Figure 1.

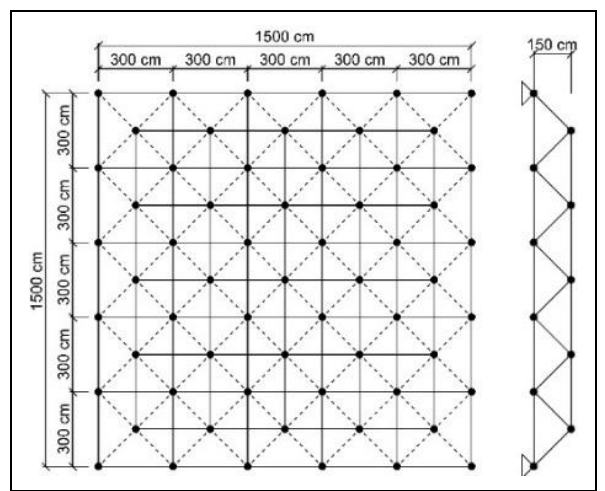

Figure 1. Plan and elevation view of space roof truss.

All truss members of the system were tubular elements, which were subjected to only axial forces. The MERO jointing system was used on nodal connections. The MERO system consists basically of bolts, sleeves and sphere, which allows to transmit forces between connected tubular bars on joints. 200 tubular bars and 61 joints were employed in each model. Since the spherical nodes transfer negligible moment, it was assumed that no any moment would be transmitted at nodes, and loads were applied on nodes as point loads. Thus, the members could be designed for only axial forces.

The truss bars (tubular bars), bolts, sleeves, and spheres were determined by elastic analysis. In design of these members, modulus of elasticity was $E=210000 \mathrm{~N} / \mathrm{mm}^{2}$ for all members. Steel material of S235, which had the yield stress of $F_{\mathrm{y}}=235 \mathrm{~N} / \mathrm{mm}^{2}$ and tensile strength of $F_{\mathrm{u}}=360 \mathrm{~N} / \mathrm{mm}^{2}$, was used for tubular bars. The yield stress and tensile strength of bolt material designated by 10.9 are $F_{\mathrm{yb}}=900 \mathrm{~N} / \mathrm{mm}^{2}$ and $F_{\mathrm{ub}}=1000 \mathrm{~N} / \mathrm{mm}^{2}$, respectively. Yield strength for sleeves was $F_{\mathrm{ys}}=355 \mathrm{~N} / \mathrm{mm}^{2}$.

In the design of considered truss roof, two limiting states were taken into consideration under compression; buckling of the tubular bars and crashing of sleeves. Besides, three limiting conditions were considered under tension; yielding of the tubular bars, fracture of the tubular bars and rupture of the bolts. As spheres were not explicitly included in the analytical models, there was no stress check for the design of spheres. However, diameters of the spheres may be proportioned geometrically so that they allow the tubular bars and bolts to be assembled at each node [12].

Final analysis and design of the Model A were conducted with SAP2000 [13], which is a commercial software, and widely used for design of structural systems. Before the final stage of the structural analysis and design checks of the Model A, several iterative analyses were performed until obtaining optimum sections of members that make self-weight minimum under service loading, which is called optimal solution, using a special software. Table 1 shows characteristics of members constituting the Model A.

In space truss structures, if many members lost their load carrying capacity due to the inelastic buckling, progressive collapse can occur [14],[15]. Also, the space truss roofs with tubular bars whose yield strengths are larger than tensile strengths of the bolts are substantially prone to brittle failure, resulting in bolt failure [16].

In order to postpone buckling failure of the truss bars with large slenderness ratios [17] and to enable some tubular bars to yield providing limited ductility, Model B was designed under some promising suggestions;

i. Limiting the slenderness ratios of the truss bars designed for compressive forces to 100 , otherwise use the limiting value of 200

ii. Limiting the slenderness ratios of the diagonal bars in compression that are connected to the support nodes to 80 ,

iii. Enabling the rupture strengths of the bolts used for the connections of the bars designed for tension to be larger than the yield strengths of the sections of the bars. Figure 2 shows the members proportioned in accordance with the suggestions above. The members of the Model B are listed in Table 2 .

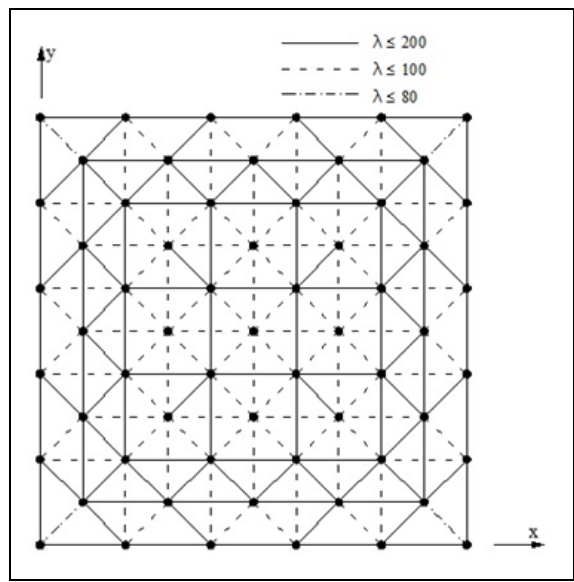

Figure 2. Truss bars of the model B. 
Table 1. Characteristics of truss bars for model A.

\begin{tabular}{|c|c|c|c|c|c|c|}
\hline Truss Member Tag & $\begin{array}{c}\text { Diameter } \\
d(\mathrm{~mm})\end{array}$ & $\begin{array}{c}\text { Thickness } \\
t(\mathrm{~mm})\end{array}$ & $\begin{array}{l}\text { Length } \\
L(\mathrm{~mm})\end{array}$ & Quantity & $\begin{array}{c}\text { Slenderness } \\
\lambda \\
\end{array}$ & Bolt Type \\
\hline 13 & 42.4 & 3 & 2598 & 76 & 186 & M12-10.9 \\
\hline 14 & 42.4 & 3 & 2598 & 8 & 186 & M16-10.9 \\
\hline 18 & 48.3 & 3 & 3000 & 52 & 187 & M12-10.9 \\
\hline $25 a$ & 60.3 & 3 & 3000 & 12 & 148 & M16-10.9 \\
\hline $25 b$ & 60.3 & 3 & 2598 & 4 & 128 & M16-10.9 \\
\hline $28 \mathrm{a}$ & 76.1 & 3 & 3000 & 12 & 116 & M16-10.9 \\
\hline $28 b$ & 76.1 & 3 & 2598 & 8 & 100 & M16-10.9 \\
\hline 36 & 88.9 & 4 & 3000 & 8 & 100 & M20-10.9 \\
\hline 41 & 88.9 & 5 & 2598 & 4 & 87 & M24-10.9 \\
\hline 50 & 114.3 & 4 & 3000 & 8 & 77 & M24-10.9 \\
\hline Truss Member Tag & $\begin{array}{c}\text { Diameter } \\
d(\mathrm{~mm})\end{array}$ & $\begin{array}{c}\text { Thickness } \\
t(\mathrm{~mm})\end{array}$ & $\begin{array}{l}\text { Length } \\
L(\mathrm{~mm})\end{array}$ & Quantity & $\begin{array}{c}\text { Slenderness } \\
\lambda\end{array}$ & Bolt Type \\
\hline 14 & 42.4 & 3 & 2598 & 48 & 186 & M16-10.9 \\
\hline $33 a$ & 88.9 & 3 & 3000 & 48 & 99 & M24-10.9 \\
\hline $33 b$ & 88.9 & 3 & 2598 & 48 & 85 & M24-10.9 \\
\hline 38 & 88.9 & 4 & 3000 & 8 & 100 & M27-10.9 \\
\hline $53 a$ & 114.3 & 4 & 3000 & 8 & 77 & M30-10.9 \\
\hline $53 b$ & 114.3 & 4 & 2598 & 4 & 67 & M30-10.9 \\
\hline
\end{tabular}

It should be noted that determination of a truss member whether it is a tension or a compression member was verified under the load combinations including gravity loads only for the sake of simplicity. However, this could be performed for a series of load combinations that are governing for strength;

i. Replace the bars with those satisfied the requirements for slenderness ratios under the load combination considered,

ii. Take the next load combination into account and leave the truss bars which are revised in previous one unchanged unless a tensile force which is likely to occur entails larger section until all load combinations are completed. Finally, serviceability requirements should also be checked.

\section{Analytical model}

\subsection{General modelling of the space roof}

Three dimensional analytical model of space roof trusses were developed by OpenSEES Software [11]. In general model, "nonlinearBeamcolumn" element was employed to define each truss bar. In this study, cross sections of the tubular bars were represented by fiber sections discretized 4 radial fibers and 16 circumferential fibers as shown in Figure 3.

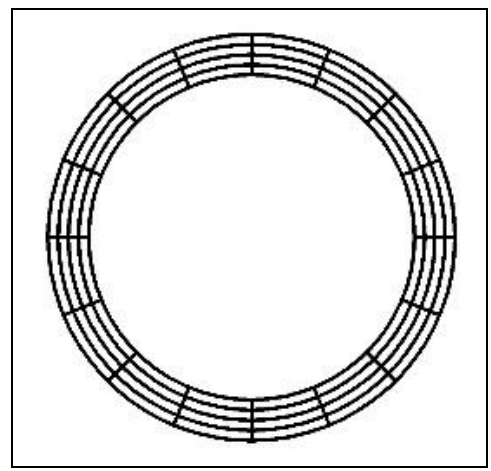

Figure 3. Discretization of the section.
Five integration points were stated along trusses. Tubular bars were designed so as to have pin-ended connection. At this point, hinge behavior was simulated by the help of "ZeroLength" element which can be used for connection modelling. "ZeroLength" element with relatively low young modulus in rotational directions provides rotational movement. On the other hand, relative translational movements were restricted to allow the axial forces to be transferred to each member being joined.

The axial nonlinear behavior of each typical member of a space roof truss, which is mainly composed of particular subelements such as a tubular bar, bolts, sleeves, and spheres was represented by a single truss element that includes the contribution of these each. Also initial imperfection was imposed on this single truss element. Hysteretic material model available in OpenSEES material library allows to characterize the element behavior by the help of six points on stress-strain diagram [8]. In order to obtain these points for each truss member, reversal cyclic loading was applied on each detailed individual truss bar, typically shown in Figure 5.

\subsection{Modeling and Individual analysis of tubular bars}

Rosen and Schmit [6] states that geometry of truss bar having initial imperfection can be depicted with half wave sinusoidal curvature. In order to determine the coordinates of the nodes along the members to impose initial imperfection, and then to develop the deformed geometry of the members, Eq.1 can be used,

$$
w_{0}=b_{0} \sin \left(\frac{\pi x}{L}\right)
$$

Where, $b_{0}$ is mid-span initial imperfection value for the member, $w_{0}$ imperfection value on desired node, $L$ is the length of the member and $x$ is distance between starting node and desired node on member (Figure 4). 


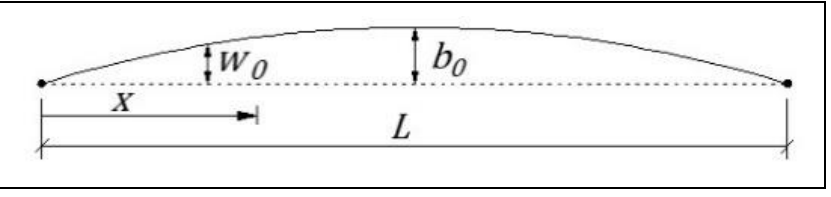

Figure 4. General configuration of initial imperfection.

For the purpose of imposing the initial imperfection into pinended simply supported truss member including bolts and spheres, tubular element was subdivided into four segments with equal length, afterwards initial imperfection values were calculated by Eq. 1 and introduced at first quarter, mid-span, third quarter node as shown in Figure 5.

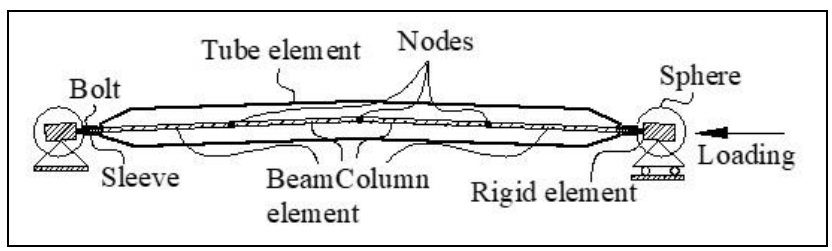

Figure 5. Typical detailed model for a truss bar.

Each four element constituting a tubular bar was modeled with a force-based nonlinear beam-column element. The discretization of member cross sections was the same as explained for the tube elements in Figure 3 [9]. Corotational transformation was considered to account for large displacements. The Giuffré-Menegotto-Pinto steel material model with isotropic strain-hardening was used for modeling steel elements [18].

Bolts and sleeves located at both ends of the tubular bars were represented by only bolts' cross sections assuming that tubular element would experience buckling while sleeves remained essentially elastic under compressive forces. Therefore, net sections of sleeves, caused by a dowel pin hole in slot form, were checked if stresses in sleeves do not reach the yield stress before buckling of tubular bars. Additionally, not any collapse reason resulted from sleeves has been reported until now. Thus, either bolt failure will occur in tension or tubular bar will buckle in compression, whichever governs the strength. In this manner, as seen in Figure 6, the connection behavior model was characterized by bolts' material properties in tension side; sleeve failure was not permitted in the compression side. In modeling of spheres, infinitely rigid elements were used since these members were not effective in determining the nonlinear behavior of space truss roofs and also have negligible deformation capability.

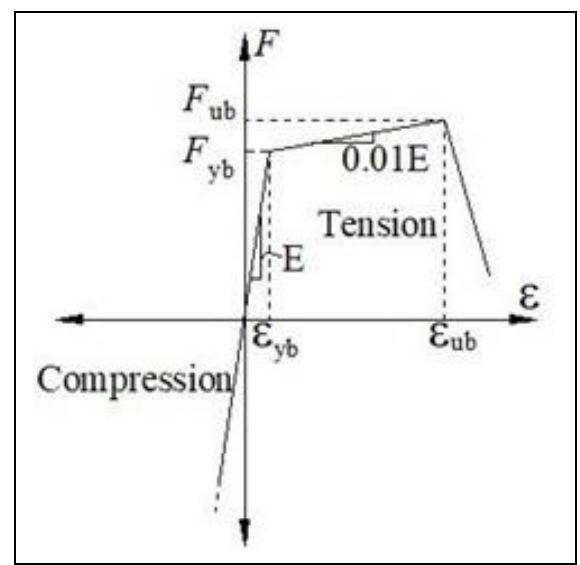

Figure 6. Behavior model of bolt and sleeve sections.
Loading history followed in the reversal cyclic loading was generated in accordance with ATC-24 [19]. According to this, truss bars were subjected to eight steps up to six times the yield displacement $\Delta$ with three cycles for first five steps and two cycles for subsequent three steps. Two steps before yield displacement were considered as $\Delta / 3$ and $2 \Delta / 3$ target displacements. For each subsequent step, target displacements were implemented as shown in Figure 7. Axial loaddisplacement curves of sample truss bars with tag of 13 and 14 are shown in Figure 8(a) and Figure 8(b), respectively. If the rupture strength of the bolts is smaller than the yield strength of the tubular bars, bolts characterize the behavior of the truss bar in tension, resulting in dramatic reduction in tensile load carrying capacity, as shown in Figure 8(a). Figure 8(b) shows the behavior of the truss bar (tag 14) with the bolts having sufficient strength. Therefore, a smooth transition takes place between critical and residual buckling loads because of the flexural deformations of plastic hinges occurred during buckling in the middle and at the ends of the truss bar. Also, as can be seen from the Figure 10, the larger amplitude of the initial imperfection causes smaller critical buckling load while it has no significant effect on the behavior in tension.

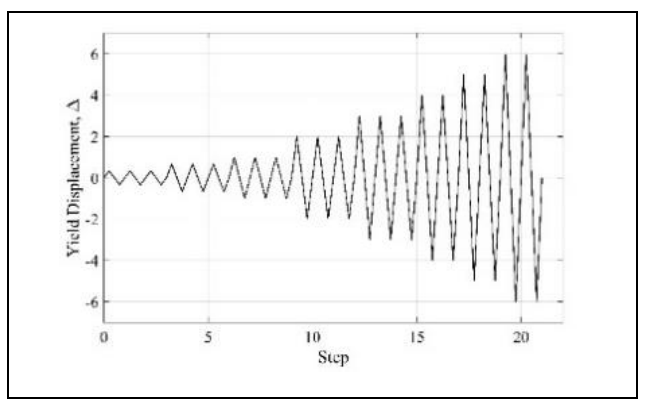

Figure 7. Loading protocol for reversed cyclic loading [19].
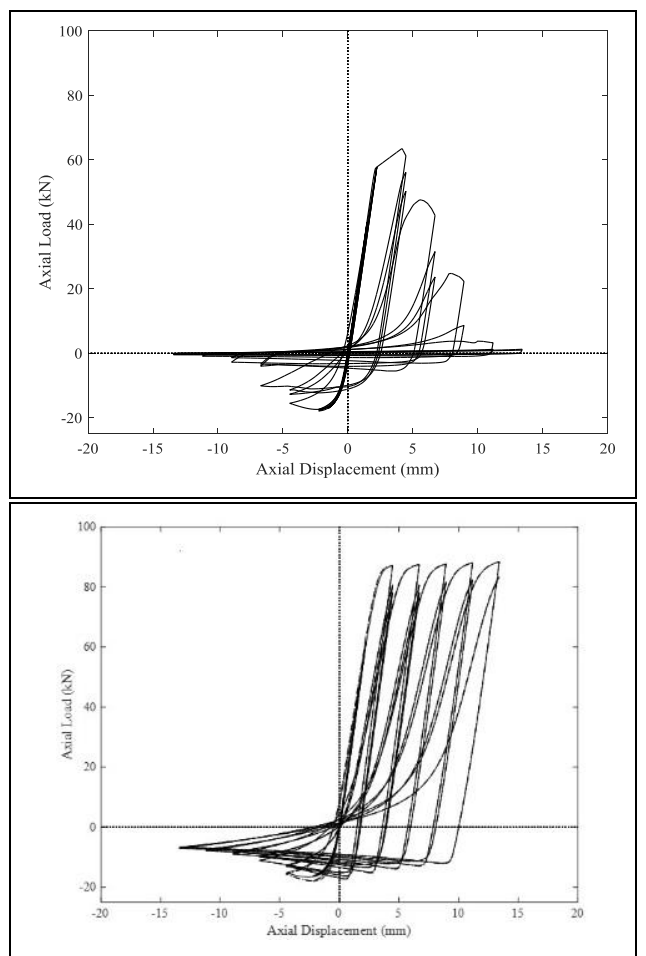

Figure 8. Axial load-displacement relationship of typical truss bars with initial imperfection $L / 300$. (a): Truss tag of 13,

(b): Truss tag of 14 . 


\subsection{Verification of axial behavior of truss bar}

To avoid the complexity of 3D analytical models, sub-elements of bolts, sleeves, and spheres were not explicitly included in the models. Instead, each truss bar was modeled with single tubular element. In addition to this, an axial plastic hinge model shown in Figure 9, which is specified in FEMA 356 [20] with the characteristics tabulated in Table 3 was customized for modeling the nonlinear behavior of all truss bars.

Table 3. Variables of axial plastic hinge model [20].

\begin{tabular}{|c|c|c|c|c|}
\hline \multirow[t]{2}{*}{ Action } & \multirow[t]{2}{*}{ Case } & \multicolumn{2}{|c|}{$\begin{array}{c}\text { Plastic } \\
\text { Displacement }\end{array}$} & \multirow{2}{*}{$\begin{array}{c}\text { Residual } \\
\text { Strength } \\
\text { Ratio, c }\end{array}$} \\
\hline & & a & b & \\
\hline Tension & & $11 \Delta_{\mathrm{T}}$ & $14 \Delta_{\mathrm{T}}$ & 0.8 \\
\hline โ & $\frac{d}{t} \leq \frac{1500}{F_{y}}$ & $0.5 \Delta c$ & $9 \Delta_{\mathrm{c}}$ & 0.4 \\
\hline 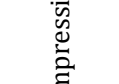 & $\frac{d}{t} \geq \frac{6000}{F_{y}}$ & $0.5 \Delta \mathrm{c}$ & $3 \Delta_{\mathrm{c}}$ & 0.2 \\
\hline ö & $\frac{1500}{F_{y}} \leq \frac{d}{t} \leq \frac{6000}{F_{y}}$ & \multicolumn{3}{|c|}{ Linear interpolation } \\
\hline
\end{tabular}

For this, a comparison was made between the backbone curve of axial force-displacement relationship shown in Figure 9 and envelop curves from the cyclic analyses of typical detailed truss bars with sub-elements to see the effect of sub-elements on the axial behavior of a truss bar without sub-elements.

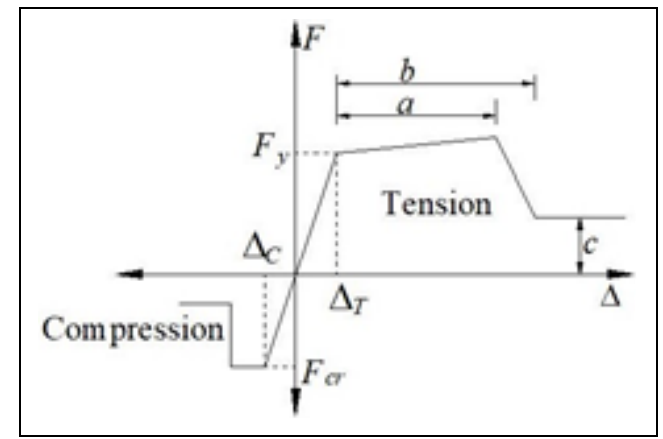

Figure 9. Axial plastic hinge model.

Based on the comparison seen in Figure 10, the cyclic response of a truss bar with sub-elements can conservatively be estimated by considering the behavior of axial plastic hinge described in Figure 9. The initial imperfection value of $L / 500$ was found to be applicable [9]. Critical buckling stress, denoted $F_{\text {cr }}$, in Figure 9 was computed according to the rules specified in AISC 360 [21] for compression members. Consequently, the nonlinear response of each truss bar with sub-elements depicted by bare truss bar can adequately be represented by the behavior model described in Figure 9. Therefore, the axial load-displacement response of each truss bar was generated based on the cyclic behavior of each obtained by OpenSEES [11] analyses and FEMA 356 [20]. Figure 11 shows the backbone curves of typical truss bars; one with the bolts whose fracture strengths are less than the yield strength of the tubular element in Figure 11(a) and another with the tubular element having yield strength less than fracture strength of the bolts shown in Figure 11(b).

\subsection{Verification of analytical model of roof system}

In order to verify the consistency between the analytical models developed by OpenSEES [11] and SAP2000 [13] model, axial forces of the members obtained from elastic analyses conducted under design loads were compared to each other.

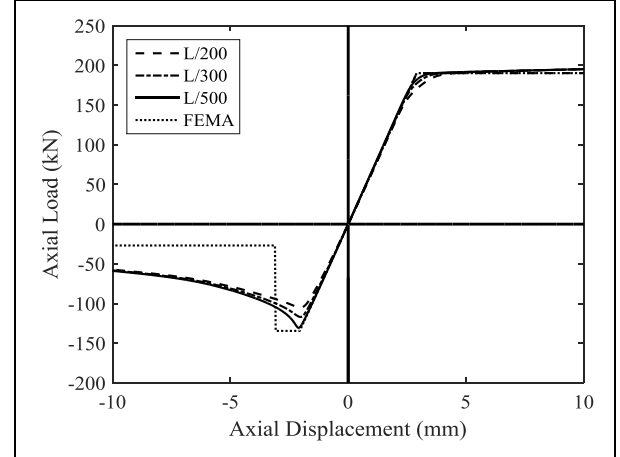

(a): Truss tag of 33b.

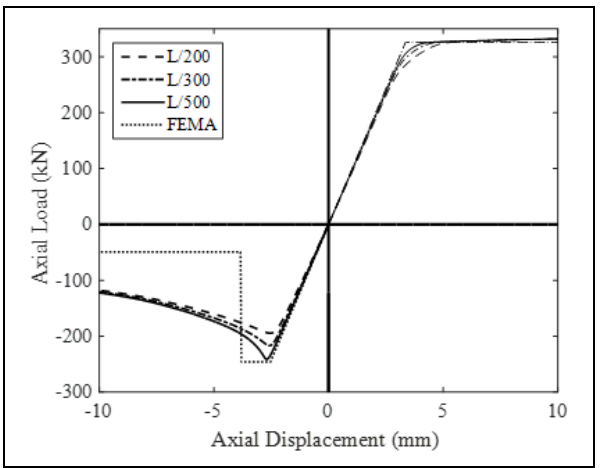

(b): Truss tag of 53a.

Figure 10. Comparison of axial load-displacement curves.

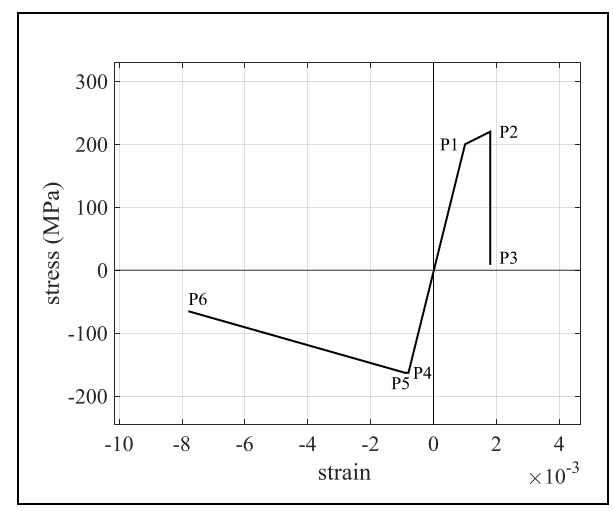

(a): Truss tag of 36.

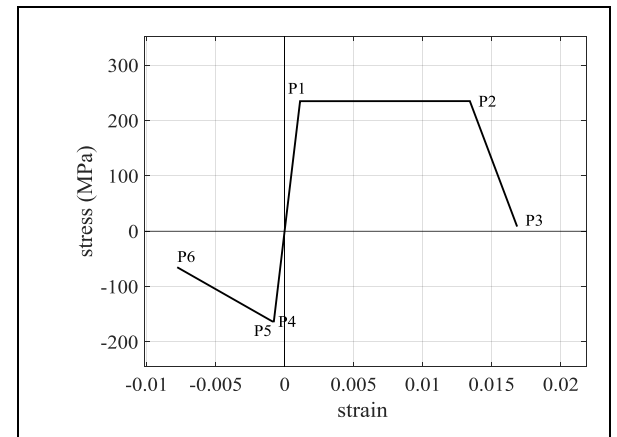

(b): Truss tag of 38.

Figure 11. Stress - strain curves of typical truss bars.

As shown in Figure 12, the consistency between the results is found to be adequate with the maximum error of $1.7 \%$. Therefore, analytical model developed by OpenSEES can be utilized for further analyses. 


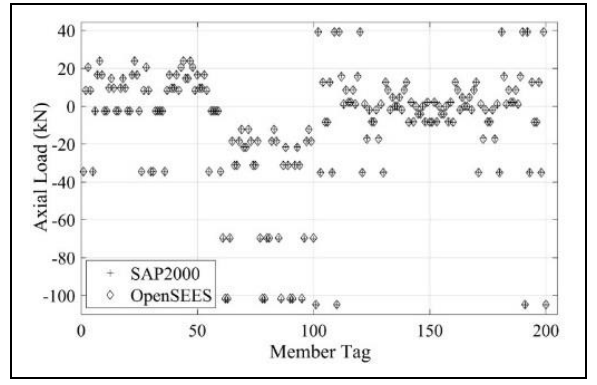

Figure 12. Comparison between the axial forces obtained by OpenSEES and SAP2000 analysis.

\section{Nonlinear analysis of space roof trusses}

Nonlinear analyses of space roof trusses were performed by OpenSEES software under monotonically incremental vertical loading. Load accumulation forms were reflected with three different load distribution scenarios, loads were accumulated on quarter, half, and entire of upper layer. The node at the center of the upper layer was chosen as the control node indicated by $\mathrm{X}$ in Figure 13.

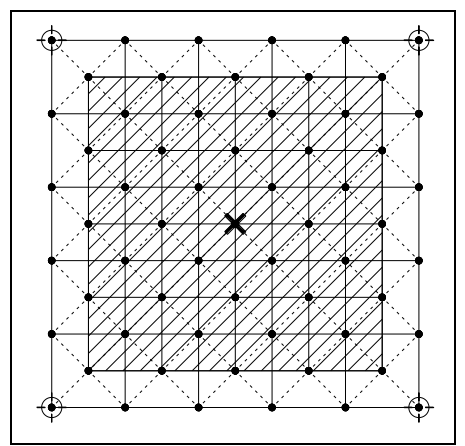

(a): Full loading.

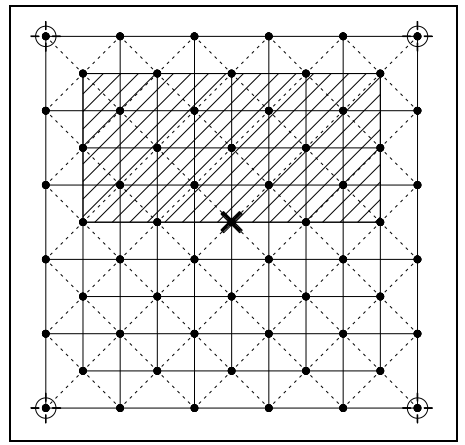

(b): Half loading.

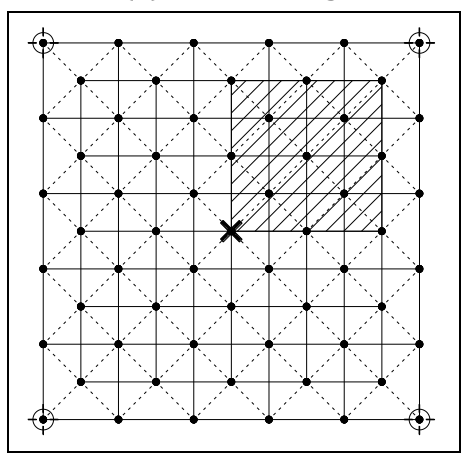

(c): Quarter loading.

Figure 13. Load accumulation forms and control nodes.
Twelve analyses whose characteristics are tabulated in Table 4 were done using the method of displacement control. Model tag of A defines the type of space truss roof designed not considering the suggestions mentioned before for Model B. Model tag of B was developed to show the efficiency of the suggestions on adding limited ductility to the loaddisplacement behavior of space truss roofs. The influence of initial imperfection was also investigated using two different peak values, i.e. $L / 300$ and $L / 500$. Loading condition implied the configuration of the load distribution over the upper surface of the roof.

Table 4. Characteristics of analyses.

\begin{tabular}{cccc}
\hline & $\begin{array}{c}\text { Model } \\
\text { Tag }\end{array}$ & $\begin{array}{c}\text { Initial Imperfection } \\
\text { Ratio }\end{array}$ & $\begin{array}{c}\text { Loading } \\
\text { Condition }\end{array}$ \\
\hline A5F & A & $L / 500$ & Full \\
A5H & A & $L / 500$ & Half \\
A5Q & A & $L / 500$ & Quarter \\
A3F & A & $L / 300$ & Full \\
A3H & A & $L / 300$ & Half \\
A3Q & A & $L / 300$ & Quarter \\
B5F & B & $L / 500$ & Full \\
B5H & B & $L / 500$ & Half \\
B5Q & B & $L / 500$ & Quarter \\
B3F & B & $L / 300$ & Full \\
B3H & B & $L / 300$ & Half \\
B3Q & B & $L / 300$ & Quarter \\
\hline
\end{tabular}

Vertical displacement at control node versus vertical base force curves obtained from nonlinear analysis under monotonically increasing vertical loading are presented in Figure 14 and corresponding failed bars are illustrated in Figure 15.

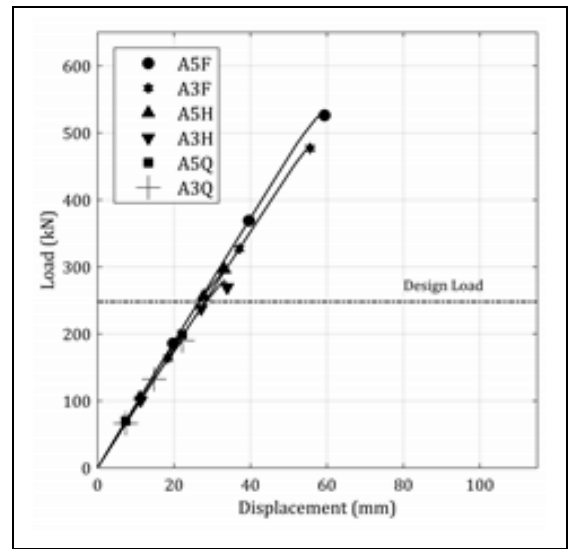

(a): Model A and.

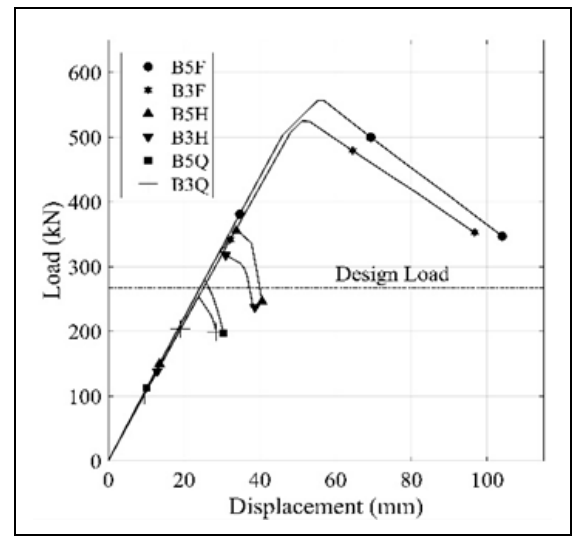

(b): Model B.

Figure 14. Load-Displacement curves for. 
The analysis results from Model A show that design of space truss roofs with no any slenderness limit applied on truss bars and no consideration on having bolts with rupture strength larger than yield strength of tubular elements makes the system sensitive against sudden failure without exhibiting ductility. This failure mechanism is a consequence of buckled truss bars which cause the roof to loss its strength. Basically, the system tries to redistribute the axial forces of failed bars [14]. However, Figure 14(a) shows that Model A cannot tolerate load redistribution because of buckled bars. Therefore, axial load redistribution triggers failure of the system and total collapse occurs suddenly.

As can be seen from Figure 14(b), it is possible to provide limited ductility for Model B by means of postponing the plastic buckling of compression bars and preventing the bolt failure before yielding of tubular bars. Moreover, if the load is accumulated on half or quarter part of the roof surface, quite limited ductility is achieved because fewer truss bars are involved in failure modes. The outstanding improvement of this model is to allow many tension members to yield, which provides limited ductility.

It is found that critical buckling load of compression members were affected negatively by increasing the initial imperfection value from $L / 500$ to $L / 300$ and if the bars with larger initial imperfection take part in the failure mechanism, load carrying capacity of the system reduced. In Model A, an increment on initial imperfection value resulted in almost $9 \%$ reduction of the strength for full loading, $6 \%$ for half and $5 \%$ for quarter area loading, while resulting in $6 \%$ for full loading, $10 \%$ for half and quarter area loading in Model B.

Location and pattern of the failed truss bars are shown in Figure 15.

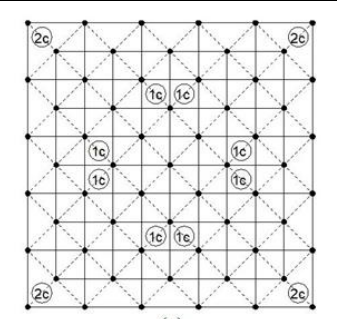

(a)

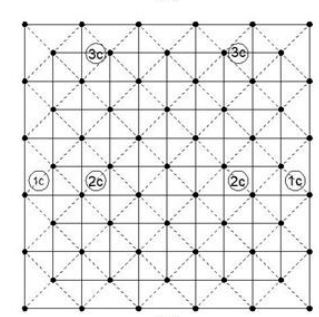

(c)

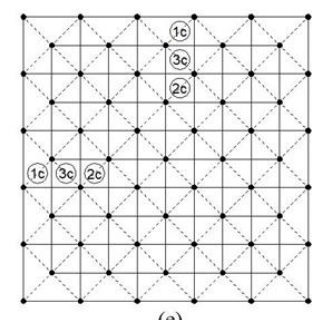

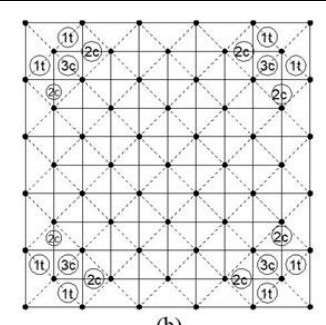

(b)

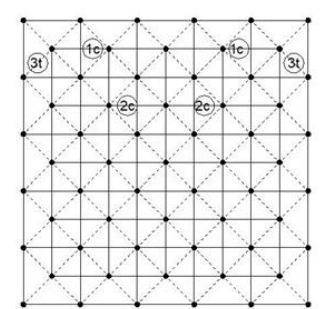

(d)

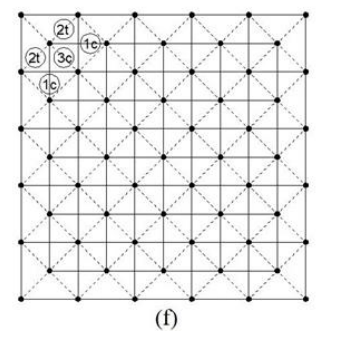

In analysis cases dealt with load accumulation on half and quarter of the roof surface, truss bar failures were monitored at local part of the roof structure. In full loading analysis case for Model A, as seen in Figure 15(a), shortly after the buckling of the first set of bars (1c), brittle failure occurs with the buckling of the second set of bars (2c) that are connected to the support nodes. According to Figs. 15(c, e) that illustrate the failed bars from the analyses under half and quarter loading, respectively, as the third set of compression bars are consecutively buckled, failed bars prevent the axial force redistribution among the bars in the near of the failed bars, then total collapse occurs in consequence of the local failure. This situation was resulted in $43 \%$ of strength reduction for half loading and $61 \%$ of strength reduction for quarter loading with respect to full loading.

Failed bars under entire surface loading for Model B are demonstrated in Figure 15(b). According to analyses results, diagonal tension bars (1t) start to yield at first providing some amount of ductility, after the buckling of compression bars (2c), diagonal bars, which are initially in tension turn into compression bars (3c) due to the fact that the system tries to redistribute the extra forces caused by the loss of many bars. Finally, the system becomes unstable because of the buckling of the bars labelled with (3c).

Whereas local failure ends up with total failure, in cases of half and quarter loading for Model B, yielding of critical tension bars provide a little ductility. As seen from Figs. 15(d, f), truss bars of (3t) and (2t) commence to yield before failure. Thus, the model exhibits more optimistic behavior due to relative ductility gained. The reduction in strength is about $37 \%$ in case of half loading while $51 \%$ of reduction occurs for quarter of surface loading with the reference to the full surface loading.

\section{Summary and conclusions}

In this study, two sample space truss roofs were exposed to several nonlinear analyses under vertical loading. The behavior of individual truss bars with initial imperfection and the contribution of sub-elements such as bolts and spheres was obtained by applying reversal cyclic loading on each truss bar. Besides, to investigate the influence of load accumulation on general response of the space truss roofs three different loading scenarios; loading on entire, half and quarter area of the upper layer were taken into consideration. Consequently, the following conclusions can be propounded;

It is inferred that using optimum sections gives the economical solution with the lack of ductility. If the failure of a space roof truss is governed by buckling of the members, the failure mode will be brittle in the absence of axial load redistribution. To prevent the space truss roof from sudden collapse and to provide limited ductility, some tension bars must yield before failure of critical compression bars. For this, the slenderness of the bars in compression needs to be limited and the yield strengths of tubular elements must be less than the rupture strengths of the bolts. As long as the amount of the initial imperfection applied to each truss bar increases the compressive strength of each decreases, resulting in the reduction in strength of the system. Load accumulation on some part of the roof surface causes fewer truss bars to be involved in determining the behavior that leads the roof to collapse since the occurrence of the axial load redistribution is confined to local area.

Figure 15. Failed bars per analysis cases. (a): A3F, (b): B3F, (c): $A 3 H,(d): B 3 H,(e): A 3 Q$, (f) B3Q. 


\section{References}

[1] Shahrabadi H. "The study of different geometrical parameter effects for single grid layers of space structure on performance level for vertical load of earthquake". American Journal of Civil Engineering, 3(2-2), 10-17, 2015.

[2] Augenti N, Parisi, F. "Buckling analysis of a long-span roof structure collapsed during construction". Journal of Performance of Constructed Facilities, 27(1), 77-88, 2011.

[3] Biegus A, Rykaluk, K. "Collapse of katowice fair fuilding". Engineering Failure Analysis, 16(5), 1643-1654, 2009.

[4] Piroglu F, Ozakgul K, Iskender $\mathrm{H}$ at al. "Site investigation of damages occurred in a steel space truss roof structure due to ponding". Engineering Failure Analysis, 36, 301-313, 2014.

[5] Piroglu F, Ozakgul K. "Partial collapses experienced for a steel space truss roof structure induced by ice ponds". Engineering Failure Analysis, 60, 155-165, 2016.

[6] Rosen A, Schmit LA. "Design-oriented analysis of imperfect truss structures-Part I". International Journal for Numerical Methods in Engineering, 14, 1309-1321, 1979.

[7] El-Sheikh A. "Effect of member length imperfections on triple-layer space trusses". Engineering Structures, 19(7), 540-550, 1997.

[8] Zhou Z, Meng S, Wu J. "Stability analysis of prestressed space truss structures based on the imperfect truss element". International Journal of Steel Structures, 9(3), 253-260, 2009.

[9] Uriz P, Filippou FC, Mahin SA. "Model for cyclic inelastic buckling of steel braces". Journal of Structural Engineering, 134(4), 619-628, 2008.

[10] Lee PS, Noh HC. "Inelastic buckling behavior of steel members under reversed cyclic loading". Engineering Structures, 32(9), 2579-2595, 2010.
[11] OpenSEES. "Open System for Earthquake Engineering Simulation". https://opensees.berkeley.edu/ (10.07.2018)

[12] Lan TT. Space Frame Structures. Editors: Chen WF, Lui EM. Handbook of Structural Engineering, 24.1-24.50, Boca Raton, FL, USA, CRC Press, 2005.

[13] SAP2000 "Integrated Structural Analysis and Design". https://www.csiamerica.com/products/sap2000 (10.07.2018)

[14] Collins IM. Collapse Analysis of Double-Layer Grids. PhD. Thesis, University of Surrey, Surrey, UK, 1981.

[15] Hamid YS, Disney P, Parke GAR. "Progressive collapse of double-layer space trusses". ABSE-IASS Symposium, London, UK, 20-23 September, 2009.

[16] Caglayan 0, Yuksel E. "Experimental and finite element investigations on the collapse of a Mero space truss roof structure-A case study". Engineering Failure Analysis, 15(5), 458-470, 2008.

[17] Grigorian M. "Performance control for efficient design of double-layer grids under uniform loading, International". Journal of Advanced Structural Engineering, 6(1), 52, 2014.

[18] Mazzoni S, McKenna F, Scott MH, et al. "OpenSees command language manual".

https://opensees.berkeley.edu/OpenSees/manuals/user manual/OpenSeesCommandLanguageManualJune2006.p df (10.07.2018).

[19] Applied Technology Council. "Guidelines for Cyclic Seismic Testing of Components of Steel Structures". California, USA, 24, 1992.

[20] Federal Emergency Management Agency. "Prestandard and Commentary for the Seismic Rehabilitation of Buildings". Washington DC, USA, 356, 2000.

[21] American Institute of Steel Construction. "Specification for Structural Steel Buildings”. Illinois, USA, 360, 2016. 